\title{
Uansvarlig om mannlig omskjæring
}

\author{
6. august 2010 presenterte NRK intervjuer med professorene Trond Markestad og Jan Helge Solbakk om \\ emnet tidlig rituell mannlig omskjæring. Deres kommentarer var ikke i samsvar med medisinsk forskning \\ og bidro trolig til en mindre saklig debatt om spørsmålet.
}

$\S 11$ i Legeforeningens etiske regler slår fast at «en lege bør etter sine forutsetninger medvirke til at allmenheten og myndigheter får saklig informasjon om medisinske spørsmål».

Markestad og Solbakk er leger med spesielt gode «forutsetninger». Markestad er professor i medisin, spesialist i pediatri og forskningsrådgiver og forskningskoordinator ved to sykehus. Han er leder for Legeforeningens etiske råd. Solbakk har vært professor i medisinsk etikk ved universitetene i Oslo og Bergen og har også utdanning som teolog.

Markestad sa i et intervju om tidlig rituell mannlig omskjæring blant jøder og muslimer at inngrepet $«$... har ingen medisinsk begrunnelse, og det strider da imot sentrale punkter i medisinsk etikk... Det

\section{«Forskningen viser med andre ord at det er medi- sinske fordeler med tidlig mannlig omskjæring»}

vanligste [av komplikasjoner] er blødninger og infeksjoner, men det jeg har sett som har vært ille, er at man har tatt for mye hud, slik at man har fått en skjevstilling av penis. Noen har også fått arrdannelser som har vært plagsomme... Jeg har gjort mange omskjæringer og jeg har sett stygge komplikasjoner etter omskjæring. I USA gjorde vi det uten bedøvelse, vi ga dem sukker og konjakk nærmest på smokk, og det var helt åpenbart at dette var smertefullt. Og ikke bare da, men det var smertefullt etterpå. Og jeg vil ikke gjøre det igjen» (1).

Solbakk tok saken enda lenger og sa: «Det er et overgrep. Omskjæring av gutter er et overgrep, på samme måte som omskjæring av jenter er et overgrep. Jeg mener det bør forbys på lik linje» (1). «Hadde ikke omskjæring vært praktisert av jøder, så hadde det vært forbudt. Man trår mer forsiktig overfor jøder enn muslimer» (2).

Mannlig omskjæring har vært gjenstand for omfattende forskning. Eksempelvis gir et søk på «male circumcision» i Medline over 3500 treff. Det er naturligvis stor variasjon i disse studiene, men omskjæring er trolig blant de mest utforskede inngrepene $i$ verden $i$ dag (3).

Når det gjelder komplikasjonene, er det gjort flere studier på dette. En retrospektiv studie med 136086 nyfødte gutter viste at blant dem som ble omskåret tidlig, oppsto det komplikasjoner hos 0,19\% (4). Ingen komplikasjoner var alvorlige. En annen studie viste en komplikasjonsrate på $0,2 \%$ blant 130457 omskårne (5). På samme måte viste en gjennomgang av 58 studier at alvorlige komplikasjoner er sjeldne, men at milde og moderate komplikasjoner oftere oppstår når barnet er eldre, det er usanitære forhold eller når den som utøver inngrepet ikke er øvet (6). Komplikasjonsraten ved for eksempel tonsillektomi (7) og brokkoperasjon (8) er betydelig høyere.

Mye tyder på at forekomsten av urinveisinfeksjon hos guttebarn som ikke er omskåret, er 8-10 ganger høyere enn hos omskårne (9), at trang forhud vedvarer hos $2-5 \%$ frem til puberteten (10) og at det hos uomskårne småbarn er høyere fare for inflammasjon av penis (11).

Forskningen viser med andre ord at det er medisinske fordeler med tidlig mannlig omskjæring. Det er det umulig å forene med Markestads fremstilling av saken, og langt mindre med Solbakks karakteristikk.

Det kan også stilles spørsmål om det prinsipielle grunnlag for kategorisk å avvise «medisinsk ubegrunnede» inngrep når det åpenbart ikke finnes etiske betenkeligheter ved å fjerne fødselsmerker, separere sammenvokste tær, gi biosyntetisk veksthormon til idiopatisk kortvokste eller sågar støtte selvbestemt abort, også hos mindreårige. «Sentrale punkter i medisinsk etikk» tåkelegges heller enn avklares med uttalelser som Markestads.

Markestads og Solbakks uttalelser har gjort klar og unødig skade. Ikke bare har allmenheten og myndigheter fătt et feilaktig inntrykk av de medisinske sidene ved spørsmålet. Muslimske og jødiske foreldre (blant andre) er med grunnlag i Markestads og Solbakks uttalelser blitt beskyldt for systematisk, med fullt overlegg og mot bedre vitende å begå «overgrep» mot sine barn.

I et land der normen blant majoriteten er å la være å omskjære guttebarna, er det forståelig at skikken vil skape forundring og forskrekkelse hos mange og hysteri hos enkelte. Ledende skikkelser innenfor medi- sinsk etikk burde være seg sitt ansvar bevisst ved å roe ned debatten med saklig informasjon. Markestad og Solbakk har i stedet utnyttet uvitenheten for å fyre opp under fremmedfrykt. De bygger på fordommer for å legitimere uvitenhet.

\section{Leif Knutsen \\ vyerllc@gmail.com \\ Gjettum}

Leif Knutsen (f. 1961) er bedriftsrådgiver og skribent, med allsidige interesser. Han har vært rådgiver for legemiddelfirmaer og helseforsikringsordninger innen bruk av IT og analytiske verktøy innenfor kunnskapsbasert medisin.

Forfatter har fylt ut ICMJE-skjemaet og oppgir ingen interessekonflikter.

\section{Litteratur}

1. Omskjæring av smågutter er et overgrep og bør forbys. NRK Nyheter 6.8.2010. www.nrk.no/ nyheter/norge/1.7238165 (25.1.2012).

2. Jødene hindrer omskjæringsforbud. ABC Nyheter 6.8.2010. www.abcnyheter.no/nyheter/100806/ jodene-hindrer-omskjaeringsforbud (25.1.2012)

3. Male circumcision: global trends and determinants of prevalence, safety, and acceptability. World Health Organization. 2007. www.who.int/ reproductivehealth/publications/rtis/ 9789241596169/en/ (25.1.2012).

4. Wiswell TE, Geschke DW. Risks from circumcision during the first month of life compared with those for uncircumcised boys. Pediatrics 1989; 83 : $1011-5$.

5. Christakis DA, Harvey E, Zerr DM et al. A trade-off analysis of routine newborn circumcision. Pediatrics 2000; 105: 246-9

6. Weiss HA, Larke N, Halperin D et al. Complications of circumcision in male neonates, infants and children: a systematic review. BMC Urol 2010; 10: 2.

7. Hanss J, Nowak C, Decaux A et al. Outpatient tonsillectomy in children: a 7-year experience. Eur Ann Otorhinolaryngol Head Neck Dis 2011; 128: 283-9.

8. O'Reilly EA, Burke JP, O'Connell PR. A meta-analysis of surgical morbidity and recurrence after laparoscopic and open repair of primary unilateral inguinal hernia. Ann Surg 2012; 255: 846-53.

9. Schoen EJ, Colby CJ, Ray GT. Newborn circumcision decreases incidence and costs of urinary tract infections during the first year of life. Pediatrics 2000; 105: 789-93.

10. Norsk helseinformatikk. Trang forhud (fimose) 22.4.2007. http://nhi.no/foreldre-og-barn/barn/ sykdommer/trang-forhud-fimose-2347.html (25.1.2012)

11. Fergusson DM, Lawton JM, Shannon FT. Neonatal circumcision and penile problems: an 8-year longitudinal study. Pediatrics 1988; 81: 537-41.

Mottatt 26.1. 2012, første revisjon innsendt 12.4 . 2012, godkjent 26.4. 2012. Medisinsk redaktør Are Brean. 